\title{
DE TWEede JEUGd VAN EEN BELANGWEKKEND LAND.
}

Statislique de l'Egypte. Année 1873, 1290 de l'Hégive. — Le Caire 1873.

\section{III.}

Zwakke punten van Egypte zijn vooreerst de politieke en sociale toostanden des lands. Hoe uitgebreid de handelsbeweging ook zij, hoezeer de kultuurondernemingen van den Onderkoning ook bloeien mogen, het lijdt geen twijfel of de ontwikkeling des lands moet eene kunstmatige blijven, staande en vallende met de persoonlijke hoedanigheden van den rorat. Alleen daar waar vaste instellingen bestaan en de ontwikkeling van de hulpbronnen des lands van onder op begonnen of van boven af diep in de verschillende lagen der bevolking doorgedrongen is, kan er genoeg stabiliteit worden aanwezig geacht voor de vreemde kapitalen, die een herlevend land als Egypte, hoe kwistig ook door de natuur bedeeld, volstrekt noodig heeft om in het leven te kunnen blijven.

Het is bekend dat de Egyptische regeering op het gebied van volksontwikkeling niet is blijren stilstaan. Groote sommen zijn uitgegeven, zoowel voor onderwijs binnenslands alis voor de ontwikkeling der fellahs, door eenigen ran hen reizen naar Europa, vooral naar Frankrijk, te laten doen; en toch hebben die uitgaven, die vooral door Said Pacha met eene meer welwillende dan verstandige mildheid werden gedaan, voor hat land in het algemeen niet veel goede gevolgen gebad. De Europeesche reizen bebben wel is waar den Onderkoning omringd van eenige ontwikkelde mannen, voor administratieve betrekkingen opgeleid, zoodat hij niet uitsluitend op de raadgevingen van aan het land evenzeer als aan de westersche begrippen rreemde Turksche ambtenaren behooft te vertrouwen, maar het algemeen peil van beschaving is door dit opkweeken van goede uitzonderingen niet aanzienlijk 
verhoogd. Alleen dan wanneer er eene goheele verandering koiut in de verhouding tusschen regeerdere en geregeerden, wanneer deze laatsten niet meer beschouwd worden als de werktuigen, waarmede de vorst zijno groote plantaadje, bet gansche land, bebouwt, en die, evenals de ploeg met zijn gespan, nu op dezen dan op genen akker, naar de willekeur van den opzichter of de eischen van den landbouw worden tewerk gesteld, - alleen in dat geval zal Eyypte kunnen bereiken het door de opvolgers van Mehemed-Ali nagestreefd ideaal, eene onafhankelijke plaats in de rij der naar Europeesche wijze ontwikkelde natien. Met andere woorden, - en hierin ligt, naar onze meening, de sleutel van Egypte's toekomst, - daar te lande zal, evenals overal elders ter wereld, de westersche beschaving en ontwikkeling eerst ter dege kunnen doordringen, wanneer men er met de oostersche begrippen zal bebben gebroken. Gouvernements-kultuur en dwangarbeid bouden de ontwikkeling tegen, zoowel boven als beneden de evennachtslijn.

Voor de instandbouding van den dwangarbeid worden in Egypte natuurlijk dezelfde argumenten aangevoerd, die zoo lang, als zuiver economische, tegen de opheffing der slavernij hebben ge¿olden, voornamelijk bij de slavenbouders zelve. Het klimaat van Egypte verbiedt den landbouwarbeid van blanken; de bevolking, net weinig behoeften, zou niet arbeiden wanneer ze niet met cenigen dwang door den landheer daartoe aangezet werd; het land zou dus met vrijheid van den arbeid door gebrek aan werkkrachten te gronde gaan, - en dergelijke beweegredenen, die werkelijk alles afdoende zijn zoodra men zich op het standpunt der uitsluitende belangen van den planter stelt. De groote plantaadje-arbeid toch gaut inderdaad wrak staan bij de oprechte toepussing van het beginsel van vrijen arbeid, en hij die de tijdelijke instandhouding dier kultuur hooger stelt dan het meer verwijderde belang der gansche bevolking, heeft, zoo hij de gevaren van een overgangetijdperk niet onder de oogen durft zien, geene andero keuze dan het laatste aan het eerste op te offeren $(*)$. Heeft deze slaud van zaken in Egypte het groote nadeel dat de vooruitgang des lands er door belemmerd wordt, - dit, zij het ook oppervlakkig geringe, doch uit een economisch zoowel als menschelijk

${ }^{*}$ ) Levert onze wet van 21 Juli 1870 , tot regeling van de op hoog gezag ingevoerde suikerkultuur, hiervan in hare bepaling sub. $3^{\circ}$. letter $g$, niet een nieuw bewijs? 
standpunt zeer groot voordeel vloeit er uit voort dat bet ongelukkige woord koelie-immigratie or nog niet heeft behoeven uitgesproken te worden. Indien deze moderne vorm van slavenbandel en slavernij niet erger en noodlottiger werkt, zoo hangt dit alleen af van het scharsehe toeval eener goede behandeling der koelies, to schaarscher omdat zij niet, zooals bij de slavernij bet geval was, dadelijk strookt met het welbegrepen belang ran den werkgever, en door het ijverigste en zorgvuldigste toezicht van overheidswege niet kan worden verzekerd.

Men slaat echter in Egypte over het algemeen te weinig het oog op hetgeen voor de hand ligt om te àoen, en verspilt moeite en schatten met het nastreven van schoone, maar langs den gevolgden weg niet gemakkelijk te vervullen wenschen.

Om een roorbeeld te geven: dat de capitulatien en de consulaire rechtspraak voor het land nadeelig zijn, ligt voor de hand. Daardoor wordt voor iederen vreemdeling een jus exterritorialitatis geschapen, dat tot weinig beter dan anarchie muet aanleiding geven. De Franschman brengt het Fransche recht, de Fransche rechtapraak en den Franachen rechter mede, zoodra hij te Alexandrie aan wal stapt; evenzoo voeren Engelschman, Italiaan, Griek, jeder de zijne met zich in het land. Bij de spreekwoordelijke immoraliteit van een zeer groot percentage van de in Egypte gevestigde vreemdelingen, behoeft het geen lang betoog, welke gevolgen deze toestand op het recht on de rechtsreiligheid der inwoners heeft $\left(^{*}\right)$. Met het grootste recht is dan ook de regeering van Egypie sedert jaren in de weer om bij de mogendheden

(*) Merkwaardig is in dit opzicht het staaltje dat Edm. About in zijne geestig geschreven (en duur betaalde) tartine over Egypte Le Fellah vermeldt. Een vreemdeling vertelt in dat verhaal dat hij, te Alexandrië van een Arabier een huis gehunrd bebbende, en wegens wanbetaling van de humpenningen voor zijneu consul in rechten betrokken, op het oogenblik dat hij de veroordeeling verwachtte, zijn huurcontract aan een ajderen vreemdeling had overgedaan. Deze betaalde evenmin, werd voor zijneu consul vervolgd en droeg au moment suprïme weder over aan iemand ran eene andere nationaliteil. "Vernits de consuls, - zoo eiudigde bet verhaal, - de roeping hebben om hunne landgenooten te beschermen, mogen zij hen niet dan met inachtneming der formaliteiten en termijnen verourdecleu. Men heeft dus altoos tijds genoeg om zich te bergeu. En daar er zeventieu cousnls te Alexandric ziju, kunt gij begrijpen hoe slecht die Arabier cr afyekomen is."

Al mar men bij het lezen van About's wcrk het korreltje zont geen oogenblik vergeten, zoo gevoelt men tocls dat er eene kern van waarheid in de meeste zijuer sterk gekleurde en overdreven voorstelliugen is. 
de opheffing der capitulatien te verkrijgen; doch zij stuit daarbij $o p$ bet natuurlijk bezwaar, - natuurlijk ook waar men onpartijdig genoeg is om de wenschelijkheid dier opheffing, in het belang des rechts zoowel als in dat ran Egyple te erkennen, - dat de genoegzambeid der inlanische reckterlijke collegien betwijfeld wordt. Eerst in den allerlaatsten tijd nu is men er op bedacht geworden on zoowel in de behoefte ran eene goede burgerlijke en strafwetgeving te voorzien als tevens te zorgen dat het gehalte der. inlandsche rechtbanken verbeterd worde. En toch had men hiermede moeten beginnen, en wanneer deze organisatie volbracht was tot de mogendheden moeten gaan on te zeggen: gij ziet dat wij zelve in staat zijn eene goude en spoedige rechtsbedeeling te verschaffen, werkt thans met ons medo om de voortaan onnoodige capitulatien op te beffen $(*)$.

$\mathrm{Na}$ deze korte uitweiding nemen wij het werk des heeren de Regny weder ter hand om te zien, wat or, zoowel door de rẹgeering als door anderen, voor de intellectueele ontwikkeling der bevolking in Egypte wordt verricht.

In de dagen van Mehemed-Ali ontvingen in Egypte omstreeks 3000 kinderen lager onderwijs; na 1862, in de eerste jaren der regeering van Said Pacha, was dit cijfer geklommen tot 60,000 ; in 1873 werd reeds aan 90,000 leerlingen lager en middelbaar onderwijs gegeven. Uit de hieromtrent door den heer de Regny medegedeelde bijzonderheden schijnt alweder to moeten worden opgemaakt, dat ook op het gebied van het onderwijs de Egyptische politiek bestaat in het hervormen van boven af, niet van onder op. Het eigenlijke volksonderwijs wordt door onzen schrijver, bij eene splitsing van alle onderwijs-instellingen naar de bronnen waaruit hare inkornsten vloeien, hoofdzakelijk gerangschiksi in do calegorie der instellingen die geheel ten laste komen van de ouders der schoolgaande kinderen. Het bijzonder onảerwijs is

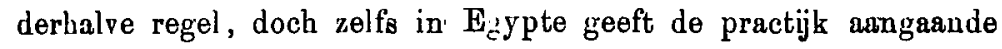
dien regel geen zeer gunstig getuigenis. In het gebeele land bestaan er 2067 dergelijke scholen, met 2067 onderwijzers en 67,859 leerlingen, verdeeld als volgt:

$\left(^{*}\right)$ Men weet dat de reorganisatie vau het rechtswezen sedert het schrijven dezer regelen zoo goed als tot stand gekomen is, schoou op eene andere dau de litir bedordde wijze. 
te Kaïro . . . . . 289 scholen, met 11,496 leerlingen

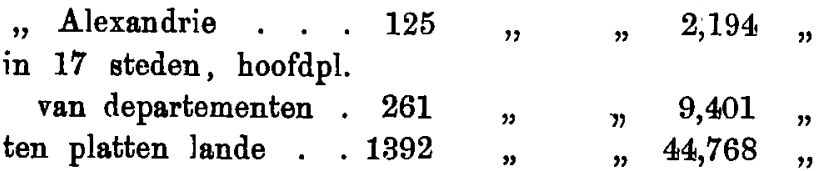

Aangaande het leerplan dezer scholen vinden wij niets medegedeeld, doch uit de omstandigheid dat elke dezer scholen, hoe groot het getal der leerlingen ook zij, slechts een enkelen onderwijzer telt, mag veilig worden afgeleid dat het onderwijs or niet veel verder gaat dan het zeer elementaire.

Voor een land met eene bevolking van meer dan 5 millioen zielen is het getal van 67,859 schoolleerlingen, die lager onderwijs ontvangen, voorzeker zeer gering; deze hef boom tot ontwikkeling is al zeer weinig krachtig. Billijkheidshalve moet men hierbij echter in het oog houden dat het volksonderwijs zich in Egypte, evenals in de meeste mahomedaansche landen, uitsluitend tot de knapen bepaalt. Eerst in den laatsten tijd, en wel sedert de laatste maanden van 1873 , is van hel onderwijs der meisjes meer stelselmatig werk gemaakt dan door de vroegere op zich zelve staande pogingen van zendelingen en geestelijke zusters geschiedde, welke uit den aard der zaak nog een bijzonder karakter hadden. De derde gemalin van Ismaël Pacha, daarin krachtig gesteund door d'en minister van onderwije Riaz Pacba en den Franschen inspecteur van het onderwijs, den heer Dor, heeft namelijk te Kaïro eene op Europeesche leest geschoeide meisjesschool voor inlandsche kinderen opgericht, welke echter nog niet in werking was toen de heer de Regny schreef. (*) Als een bewijs van vooruitgang kan hier tevens worden vermeld dat, blijkens eene opgave van den heer de Regny in zijne statistiek van Egypte over 1869-70 (Première année) het getal der bovenbedoelde volksscholen in 1869 te Kaïro

(*) Door den heer Ridgway, gewezen hoofdbestuurder van de normaalschool te Culham, in Engeland, wordt een zeer ginstig oordeel uitgesproken over de bedoelde, door hem bezochte instelling, in ecn artikel in de Times van $3 \mathrm{April}$ 1874. Zij werd in November 1873 opgericht, is geheel kosteloos, en telde in Mnart 1874 reeds 306 leerlingen, waarvan 206 in de inrichting gehuisvest en gevoed werden. De meisjes, van 7 tot 12 jaar, ontvangeu daar onderwijs in lezeu, schrijven, rekenen, de inlandsche taal, nuttige vrouwelijke haudwerken, aardrijks. kunde en vreemde talen. (De beide laatste vakken zullen worden onderwezen naar mate de leerlingen deu cursus verder zulleu hebben afgeloopen.) Ouk worden de internes om benrten met het bezorgen van de hnishonding en het huishondelijk werk belnst. 
en Alexandrie bedroeg 259 (tegen 414 in 1873) met 7620 leerlingen (tegen 13,670 in 1873), en dat het getal leerlingen op de scholen dezer categorie in geheel Egypte in dat jaar omstreeks 60,000 beliep.

De verder bestaande scholen van lager onderwijs verhoogen bet totaal der schoolleerlingen niet aanzienlijk. Zij worden gedeeltelijk bekostigd door de regering, door de kerk (indien men hare bekostiging uit de inkomsten der moskeegoederen, wakkufs, met dezen term noemen mag), en door bijdragen der ouders; dit laatste element van bestrijding der kosten ontbreekt alleen bij de scholen voor arme en weeskinderen.

De scholen, waarop schoolgeld wordt betaald zijn drieërlei : de zoogenaamde centrale scholen, in de hoofdplaatsen der departementen, waarvan er in 1873 eerst drie aanwezig waren, to Benigoeëf (270 leerlingen), te Benha (262 leerlingen) en te Sioet (213 leerlingen.) To Minieh. Tanta en Mansoera zouden in den loop van dat jaar nog drie dergelijke worden gevestigd, voor 270, 400 en 300 , leerlingen ingericht. $\mathrm{Zij}$ worden bekostigd uit de inkomsten der daarvoor speciaal aangewezen moskeegoederen, met de opbrengst der schoolgelden en subsidiën van den Staat. Verder bestaan er te Kaïro 18 gezindheidsscholen: 10 (waaronder 2 voor meisjes, met 136 leerlingen) van de Koptische Chriatenen, 4 Israëlitische, 3 Syrisch- en 1 Armenisch-Christelijke. Ook deze worden door subsidiën van rijkswege ondersteund; zij telden in 18731002 leerlingen.

Zuiver mahomedaansch zijn de 16 , min of meer op de leest der Fransche lycées geschoeide kostscholen te Kaïro en Alexandrie, met 1358 leerlingen; de uitgaven worden gedekt door de inkomsten der. moskeegoederen, bijdragen van bijzondere personen en schoolgelden. De leerlingen worden aldaar gehuisvest, gevoed en gekleed, en ontvangen onderwijs in de volgende vakken: de kennis van den Koran, de beginselen van den godsdienst, de Arabische on 'Turksche talen; in sommige dezer scholen worden darenboven onderwezen de Europeesche talen, de geschiedenis, de aardrijkskunde en de cijferkunst. De onderwijzers, 74 in getal, worden door den minister van onderwijs anngesteld; het schoolgeld bedrangt, naar gelang van de gegoedheid der ouders, 5, 10 of 15 piasters 's maands voor olken leerling.

Scholen voor arme en weeskinderen bestaan te Kairo (408 leerlingeu) en te Alexandrio (100 leerlingen); zij worden bekostigd nit de inkomsten rer moskeegocderen met aubsidie van de prigeen 
ring. Het onderwijs in deze scholen bepaalt zich niet tot de Arabische en Turkeche, maar ompat ook voor de geschikte leerlingen de Europeesebe talen. In 1873 leerden 92 ven dezen Fradsch, 38 Engelsch, 29 Duitseb. Ook worden de leerlingen in sommige takken van handwerksnijverheid, als timmeren, verven, enz. opgeleid.

Van al deze verschillende lagere scholen bereikte het getal kweekelingen dus het totaaleijfer van 71,472 .

Tot het middelbaar onderwije zijn te brengen de volgende pakscholen: vier militaire scholen, tot vorming van officieren'van den generalen staf, artillerie, cavalerie en infanterie, met 423 kweekelingen: een mathematische met 18 ; een veeartsenjikundige met 24; een landbouwschool met 34 leerlingen; de polytechnische school ( $67 \mathrm{kweekelingen);} \mathrm{die} \mathrm{tot} \mathrm{opleiding} \mathrm{van} \mathrm{schrijvers} \mathrm{en}$ landmeters (64); de school der arts et métiers (42); de kwoekschool voor vroedvrouwen (21); de archeologische school (7); de pormaalschool tot opleiding van onderwijzers; de scholen tot voortereiding voor het middelbaar onderwijs (met 742 leerlingen), allen bekostigd door den Staat en gevestigd te Kaïro of te Alesandrie.

Als inrichtingen van hooger onderwijø kunnen vermeld worden: de sckool voor rechtsgeleerdheid en letterkunde (37), die voor geneeskunde en artsenijmengkunde (85), wier doel echter minder is het bevorderen van breede wetenschappelijke ontwikkeling dan het vormen van advocaten, translateurs, civiele en militaire artsen en apothekers. Bovendien de mahomedaansche universiteit El-Azhar te Kaïro, met 314 onderwïzers en 9441 leerlingen, die zich do opleiding van mahomedaansche priesters en wetgejeerden ten doel stelt.

De niet-Egyptische scholen zijn 70 in getal en worden door 4321 knapen en 2882 meisjes, meest kinderen van in Egypte gevestigde preemdelingen bezocht. Het zijn hoofdzakelijk scholen van verschillende zendinggenootschappen el katholieke taiesien; de meerderbeid is te Kaïro (26) en te Alexandrie (28) gevestigd, de andere in tien verschillende plaatsen an het Suez-kanaal en aan de Nijl. Een groot gedeelte dezer scholen, die geacht kunnen worden geheel buiten het eigenlijke volksonderwijs te staan, worden door den Staat gesubsidieerd.

Betreffende den materieelen toestand der bevolking worden in de statistiels van Egypte niet veel opgaven aangetroffen. Van elders is het echter genoegzaam bokend dat die veel te wenschen overlaat, dat woning, kleeding en voeding der fillabs zeer geEcos. 1875. 
brekkig zijn en primitief, en dat de stroom van geld, dien de kultuurondernemingen van den Onderkoning in het land brengen, gewoonlijk over de hoofden der bevolking heen wegvloeit om enkelen te verrijken. De door den heer de Regny medegedeelde opgaven en cijfers betrekkelijk de door inlanders uitgeoefende beroepen en bedrijven zijn verre van volledig. Zoo wordt slechts van vijf van de vijftien moediriels medegedeeld hoeveel personen er zich wet den landbouw bezig bielden, namelijk 170,915 kleine grondeigenaars (beter wellicht arbeiders voor eigen rekening) en 155,816 loontrekkende arbeiders. De arbeidsloonen voor de laatstgenoemden verschilden in de verschillende streken tusschen de $1_{4}^{\frac{1}{4}}$ en $2 \frac{3}{4}$ piaster per dag.

Ook omtrent het getal werklieden, in de talrijke en velerlei gouvernementsondernemingen gebezigd, zijn de opgaven zeer schraal. Voor de katoen- en suikerteelt, die meest in heerendienst gescbiedt, ontbreken die geheel, even als voor de wapenfabrieken en geschutgieterijen to Kairo, voor de garnizoens- en armenbakkerijen to Alexandrie, de gouvernementsleerlooierij te Kaïro enz. Daarentegen wordt vermold dat de gouvernementslakenfabrieken te Boelak en Choebra 1438 werklieden tellen, de marinewerven en het arsenaal te Alexandrie 558, de hoofddoekenweverij te Foeëh 174, de papierfabriek en gouvernementsdrukkerij te Boelak 218. Het bedrag der loonen wordt niet opgegeren.

In de eerste jaargangen der statistiek van Egypte kwamen zeer uitvoerige opgaven voor van de door inboorlingen in de steden Kaïro en Alexandrie uitgeoefende vrije beroepen en bedrijven. In den jaargang 1871 liep deze uitgave over Kaïro en bevatte 150,066 personen; in 1872 liep zij over Alexandrie en bevatte 25,940 personen, in 142 gilden of corporatien verdeeld, terwijl het getal niet tot die gilden behoorende neringdoenden en kleine industrieelen in de laatstgenoemde stad op 25,113 daarboven werd geschat. Over 1873 wordt deze opgave gedaan roor eenige takken van industrie, in groote groepen verdeeld. Dat zij zeer onvolledig is blijkt daaruit, dat deze categorien over geheel Egypte slechts van 105,956 in handwerksnijverheid en kleinhandel werkzame personen rekenschap geven, terwijl uit de vermelde cijfers is af te leiden dat reeds meer dan 200,000 personen in de twee genoemde steden tot den neringdoenden en industrieelen stand behooren. Wat echter aan de opgaven eenige waarde geeft is de vermelding van het arbeidsloon, dat in elke dezer groepen van industrie verdiend wordt. 
In de eerste categorie komen alle beroepen en bedrijren voor, in verband staande met chemische producten, als: parfumerien, plantaardige oliën, bougies, enz. Zij bevat 6664 mannen en 18 vrouwen, wier dagloon, voor de werklieden aan de oliepersen, gemiddeld 7 piasters bedraagt.

De categorie der met voeding in verband staande industrie omvat de verkoopers van verschillende eetwaren, koffiebuishouders, molenaars, bakkers, enz.; zij telt 35,321 w. en 2400 v. Het gemiddelde loon voor alle onderdeelen dezer categorie bedraagt in de rerschillende oorden des lands $2 \frac{1}{2}$ à 5 p. per dag.

Van de suikerfsbrieken wordt het getal werklieden niet opgegeven, doch wel het loon, hetwelk, in evenredigheid van leeftijd en kracht, van 6 tot 16 p. per dag beloopt.

De op de kleeding betrelsking hebbende industrien, de bereiders van stoffen, kleedermakers of verkoopers, en fabriekanten van passement, knoopen, enz. bezigen 28,200 mannen en 68 vrouwen, met een dagloon van $3 \frac{1}{2}$ à 5 p.

De vervaardigers en verkoopers van lederwerk, als zadels, emmers, wijnzakken, de looiers, enz. tellen $2865 \mathrm{~m}$. en $4 \mathrm{v}$.; de arboiders trekken van $4 \frac{3}{4}$ tot $10^{3}$ p. daags.

De werklieden in de metaalindustrie, waaronder goud- en zilversmeden, loodgieters, horlogemakers, zwaardvegers, smeden on dergeijjken te verstaan zijn, $6827 \mathrm{~m}$. en 2 vr. in getal; de verdiensten van 4 tot $6 \frac{1}{2}$ p. per dag.

De categorie van den houthandel en de houtindustrie geeft aan $16,940 \mathrm{~m}$. werk, en levert van 3 tot $8 \mathrm{p}$. dagloon.

Voor de industrie van glas- en aardewerk in baren ganschen omvang, zoowel de verrers, glazenmakers als de polijsters van marmer en de kooplieden in rozenkransen omvattende, worden $5902 \mathrm{~m}$. en 83 v. als arbeidende tegen een dagloon van $2 \frac{1}{2}$ tot $9 \frac{1}{2} \mathrm{p}$. vermeld.

Eindelijk zijn 662 mannen werkzaam in de industrie van boekhandel, typografie, lithographie, enz., tegen een dagloon van 9 tot $12 \frac{1}{4} \mathrm{p}$.

Al deze opgaven betreffen de particuliere industrie, alleen met nitzondering van die belreffende de suikerfabrieken, waar bet opgegeven dagloon in de fabrieken van den Onderkoning wordt uitbetaald. Het hoogste dagloon van de particuliere induatrie is dus niet meer dan $12 \frac{1}{4}$ p., nog geen $f 1.55$, en wordt, blijkens de opgaven, door de letterzetters te Kaïro verdiend. Mogelijk zijn al deze loonen in overeenstemming met de behoeften des lands dat ze echter zeer verre van een matig, gezwegen van boog, loor 
verwijderd blijven, vooral waar het de overgroote meerderheid der bevolking, de veldarbeiders, geldt, die zich hier en daar met nog minder dan 25 cents daags terreden moeten stellen, zal wel niet behoeven betoogd te worden.

IV.

Een kort en duidelijk overzicht van de financien van Egypte vindt men in het werk van den heer de Regny evenmin als in de vele officieele en officieuse bescheiden die nu en dan daaromtrent worden openbaar gemaakt. Vertrouwbare gegevena zouden hieromtrent waarschijnlijk menigen Nederlander zeer welkom zijn, daar met Egypte, evenals met zoo menig ander land, onze handelsbetrekkingen onbeduidend, doch de betrekkingen onzer couponknippers zeer innig geworden zijn. Egypte heeft in de laatste tien, twaalf jaren ontzaglijke sommen geleend; men noemt fabelachtige eijfers van het bedrag van de vlottende schuld en geeft hoog op van de zeer bezwarende voorwaarden, waaraan het gouvernement zich moet onderwerpen om geld te bekomen, - heel veel meer weten de Nederlandsche renteniers niet omtrent de toekomst en de veiligheid bunner naar de Nijlstreek vervoerde kapitalen.

Het licht, dat uit de statistiek to putten is, volgt hierachter; het zijn de budgetlen der regeering voor-het mahomedaansche jaar 1286 (12 April 1869-1 April 1870) en voor de koptische jaren 1588 on 1589 (11 Sept. 1871-73). Daarbij volgt een kort overzicht van den door de EgyptiBche regeering in de laatste maanden van 1873 openbaar gemaakten staat, aanwijzende de werkelijke uitgaven over het 11 Sept. bevorens geeindigde tienja. rig tijdvak, in groote rubrieken verdeeld. Bij deze opgaven en bij het beoordeelen van alle berichten aangaande den financieelen toestand van Egypte en de hooge cijfers van de vlottende schuld, mag echter eene omstandigheid niet uit het oog verloren worden, die velen over het hoofd zien: de geheele afseheiding die er bestaat tusschen de eigenlijke Egyptische startsfinancien en de daïra, de particuliere domein-administratie van den Onderkoning. Van de laatstbedoelde weten wij niets; geen enkel eijfer, geen enkel onderdeel der comptabiliteit is ons bekend. De daïra is, feitelijk althans, in het bezit van het monopolie der suikerkultuur; ook andere kultuurondernemingen en een aantal takken van nijverheid worden door baar gedreven, waarvoor een aanzienlijk, 
bewegelijk kapitaal wordt vereiseht. Vandaar de herhaalde roorschotten, tegen 10,12 ja 20 percent door bankiers verleend op korten termijn op rekening van verscheepte katoen, suiker enz. Wie deze voorschotten tot de vlottende schuld van Egypte rekenen wil, op het voorbeeld van $l e \mathrm{Nil}$, een blad dat de republikeinsche beginselen onder de fellahs predikt en oppositie tegen den Onderkoning voert, bedriegt zich. Slechts dan wanneer men de som van alle particuliere schulden in een land als een integreerend deel van de staatsschuld beschouwt, kan or van zulk eene optelling sprake zijn. Dan voorzeker zouden de obligos van Egypte en de Egyptenaren een zeer hong cijfer geven; maar dit zou wel bij elk handeldrijvend land het geval zijn, en toch niets op de solvabiliteit der regeering afdoen. De overdreven ongunstige voorstellingen, die men zich hierom van de vooruitzichten der houders van Egyptische fondsen maakt zijn vooral daarom niet gemotiveerd, omdat inderdaad de toekomst der financien van dit land, gelijk uit de volgende mededeelingen blijken zal, verre van rooskleurig is.

De budgetten van de drie bedoelde jaren luiden bij den heer de Regny (de cijfers in Ned. guldens) als volgt:

IN KOM $8 \mathrm{TEN}$.

\begin{tabular}{|c|c|c|c|c|}
\hline & Mab. jaar 1286. & Kopt. jaar 1588. & Kopt. jaar 1590. & Kopt jar 1590 \\
\hline Grondbelasting . . . . . & & $f 56,545,000$ & $f 48,505,000$ & 25,000 \\
\hline Tienden van den dadeloogst. & & $1,787,000$ & $1,787,000$ & $2,270,000$ \\
\hline Patentbelasting . . . . & & $1,944,000$ & $1,94,4,000$ & $3,576,000$ \\
\hline Verschillende belastingen. & $f 64,338,000$ & $1,084,000$ & $1,345,000$ & \\
\hline Rechten op de olie. . . . . & & 274,000 & 175,000 & \\
\hline Pacht van gouvernementsgrondeu & & 373,000 & 555,000 & $3,395,000$ \\
\hline Quarantainerechten. . . . & & 8,000 & 8,000 & \\
\hline In- en uitvoerrechten : & $6,552,000$ & $6,176,000$ & $6,600,000$ & $7,425,000$ \\
\hline Inkomsten der spoorwegen &, 000 & $7,036,000$ & $9,375,000$ &, 000 \\
\hline "vau Soelau. & 000 & 0,000 & &, 000 \\
\hline Belasting op het zout. . . . . & 7,000 & $2,187,000$ & $2,089,000$ & $3,075,000$ \\
\hline aandeelen Suez-kanaalm $m_{i j}$. & $2,128,000$ & 8,000 & $2,128,000$ & $2,128,000$ \\
\hline Zegelrecht en waarborg . . . & 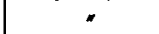 & 000 & $2,315,000$ & " \\
\hline Vroon-, sluis- en dergelijke rechten & $3,233,000$ & $3,234,000$ & $3,234,000$ & $2,250,000$ \\
\hline $\begin{array}{l}\text { Inkomst. van gouv. gronden en over- } \\
\text { gangsrecht van vaste goederen. }\end{array}$ & “ & $2,320,000$ & $2,320,000$ & $" 1$ \\
\hline Marktgelden, rechten van de olie- & & & & \\
\hline persen, belast. op de schapen enz. & $2,320,000$ & * & " & . \\
\hline Diverse indirecte belastingen. . & $2,191,000$ & * & " & $3,405,000$ \\
\hline Bel. op de granen, weegloonen enz. & 750,000 & * & $"$ & " \\
\hline Inkomsten der gouvernementen. . & $"$ & $2,532,000$ & $2,536,000$ & \\
\hline Baten der pakketvaart en sleepdienst & - & " & 335,000 & 625,000 \\
\hline Vuurgelden . . . . . . . . & " & “ & 10,000 & " \\
\hline Moekabelah . . . . . . & . & " & '" & $19,700,000$ \\
\hline An nuiteit voor aflossing van de voor & $"$ & 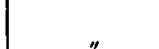 & & \\
\hline Tabaks belasting. & 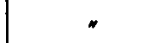 & $"$ & " & $6,250,000$ \\
\hline & & & & 429,000 \\
\hline
\end{tabular}


U I'T G A V E N. (*)

Civicle lijst van den Onderkoning.
Leden van ziju huis. . . .
Schatting aan de Porte . . . .
Geheimen Raad en Dep. v. Bint. Zak.
Departenent van Financien . .
\[ " \text { " Buitenl. Zaken . } \]
" Oorlog. . . .

Justitieraden in steden en prov. Dep. van Openb. Werken $\left\{\begin{array}{l}\text { personeel } \\ \text { materieel }\end{array}\right\}$ Geneeskundige dienst en hospitalen Divan-raden in de steden. . . Bestuur der provinciën . ... Politic te Kairo en Alexindrié. Departement van Onderwijs. . Douanebestuur : $:$ - . . . Pensioenen van de harems . Pensioenen . . . . . . . . Verloftractementen en wachtgelden. Toelage aan pelgrims waar Mekk Rente op aaud. Suez-kanaalmaits Kosten der staatsschulden . . Buitengewone werken aan de Nijl. Verschillende uitgaven. . . . Onvoorzieue uitgaven . . . . .
Spoorvegen en telegrafen.

\begin{tabular}{|c|c|c|c|}
\hline Moh. jiar 1286 . & Kю|'. jn:tr 1588. & 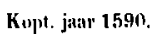 & $\begin{array}{l}\text { Kupt. jaar 1590 } \\
\text { (gerertificeerd). }\end{array}$ \\
\hline$f 3,750,000$ & $f 3,750,000$ & $f 3,75$ & $f \quad 3,750,000$ \\
\hline $1,384,000$ & $1,384,000$ & $1,751,000$ & $3,281,000$ \\
\hline $8,229,000$ & $8,229,000$ & $8,229,000$ & $8,350,000$ \\
\hline, 000 & 335,000 & 273,000 & \\
\hline $1,910,000$ & $1,871,000$ & $1,871,000$ & $2,975,000$ \\
\hline 121,000 & 118,000 & 104,000 & \\
\hline 8,75 & & 8,75 & 8,85 \\
\hline 2,8 & 2,625 , & 2,625 & $1,112,000$ \\
\hline $5,062,000$ & 420,000 & 420,000 & 4 \\
\hline 143.000 & $\begin{array}{r}223,000 \\
7,910,000\end{array}$ & $9,725,000$ & $6.512,000$ \\
\hline $\begin{array}{r}49 \\
1,56\end{array}$ & & $2,618,000$ & $2,502,000$ \\
\hline 2,0 & 1,85 & & $\mathbf{5 , 2 8 7 , 0 0 0}$ \\
\hline 1,20 & 1,11 & 1,11 & 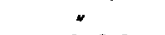 \\
\hline & & & 650,000 \\
\hline & & 353,000 & 437,000 \\
\hline & 22 & & \\
\hline $1,920,000$ & 2,664 , & & \\
\hline 406,000 & 535,000 & 000 & $2,987,00$ \\
\hline & & & \\
\hline 2,128 & 2,12 & 2,128 & $2,128,000$ \\
\hline $37,316,000$ & $30,213,000$ & 22,40 & $51,837,000$ \\
\hline 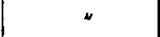 & " & 2,41 & 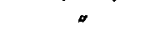 \\
\hline$"$ & $"$ & & r. \\
\hline $2,500,000$ & $2,500,000$ & $2,500,000$ & $3,125,000$ \\
\hline " & " & $"$ & $5,450,000$ \\
\hline & & & \\
\hline
\end{tabular}

Men ziet dat deze ramingen, vooral wat de inkomsten aangaat, slechts als zeer globaal zijn aan te merken; de groote groepen, waarin de belastingen worden ingedeeld en het menigvuldige ens. brengt dit aan den dag, de afwijkingen in de cijfers bevestigen bet. Toch geven de eijfers, al kent men hun slechts geringe waarde toe, tot eenige opmerkingen aanleiding.

In de eerste plaats valt de vermindering van het eindeijfer der inkomsten in het oog. Bij de opbrengst der grondbelasting voornamelijk, en dáár juist te gevaarlijker omdat deze belasting de hooflbron van inkomsten van Egypte uitmaakt. Zij bestaat gedeeltelijk in den vorm eener tiend, achoer, van 10 à 60 piasters per feddan, gedeeltelijk als eigenlijke grondbelasting, amoeat, die

(*) De laatste folom van deze twee staten bevat het gerectificeerde budget voor 1590 , gelijk het door de Egyptische regeering in den zomer van 1873, kort na het uitschrijven der leening, werd openbaar gemaakt. De anmerkelijke verschillen in de cijfers van dit gerectificeerde en het oorspronkelijke budget geven, gelijk de Engelsche Economist opmerkt, reden genoeg om aan geen van beiden veel vertrouwen te schenken. 
40 à 150 piasters per feddan belocpt. Dexe rerminilering is grootendeels toe te ochrijven an de moekabelal, eene instelling, omtrent welker eigenlijk karakter de officieele slukken niet veel lichts verspreiden. De heer de Regny noemt haar: une combinaison financière, qui a admis les contribuables à liberation facultative de six années d'anticipation, moyennant certaines condilions, en vue de l'extinclion de la detle flottante. In de algenseene schuldbekentenis van de Egyptische regeering, als bewijs van de leening van 1873 bij de Engelsche bank gedeponeerd, spreekt de Onderkoning zelf er van als: engagement pris par les propriétaires et garanti sur les immeubles pour la libération de la moitié des impöts fonciers; een der emittenten van dezelfde leening eindelijk noemt haar, in eene onlange bekend gemaakte financieele mededeeling: a measure for redeeming part of the landtaxes by payments spread over twelve years. Al stemmen deze omschrijvingen niet geheel overeen, zooveel is toch zeker dat de moekabelal neerkomt op het slachten van de kip, die gouden eieren legt. De grondbelasting zal dus minder opbrengen, hoe grooter de buitengewone inkomsten zullen zijn van de kapitalisatie.

De post in ontrang voor rente op aandeelen aan de Suezkanaalmaatschappij gaat op tegen een gelijklnidenden onder de uitgaven. De Staat heeft namelijk voor een zeker tijdvak afstand gedaan van die rente ten behoeve van de kauaal-inaatschappij zelve. Wanneer men het oog laat gaan over de voorwaarden waarop de bankiers aan Egypte geld plegen te bezorgen, dan kan dit middel van ondersteuning aan de maatschappij in de hoogste mate voordeelig voor de schatkist worden genoemd.

De zeer groote verschillen in de raming van dezelfde posten voor verschillende jaren vinden in het werk van den heer de Regny geen de minsto opheldering.

Meer waarde dan deze, blijkbaar zeer ruw geraamde budgetten Leeft het overzicht, dat de regeering van Egypte onlangs uitgaf van alle werkelijke ontvangaten en uitgaven des lands van 11 Sept. 1863-1873. De eindcijfers daarvan waren de volgende:

\section{ON'T VANGS'IEN.}

a. Aan belastingen en helfingen van allerlei aard, uitgezonderd in- en uitgaande rechten 00 in $1867-68$ - 75175000 : in $1872-73 f 77,225,000$.

b. Aau iukomsten vau de spoorwegen . . . . . . . . . - 49,983,000 in $1863-64 f 2,800,000$; in $1867-68 \dot{8}+300,000$; in $1872-73 f 7,687,000$. 


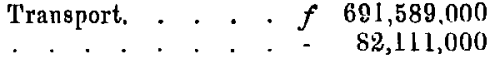
in $1863-64 f 15,061,000$; in $1867-68 f 5,8011,000$; in $1872-73$ f $7,697,000$.

d. Aan opbrengst der moekabelah . . . . . . . . . . - 101,290,000 als : in $1871-72 f 62,400,000$; in $1872-73 f 38,890,000$

Daarenboven werden de volgende, geheel buitengewone ortvangsteu gedaan :

Opbrengst der leening van 1864 . . . . . . . . . - 59,960,000

$"$ " " " $" 1868$ (voor spoorwegen)
$"$ "

\section{UI'IGAVEN.}

10. Schatting aan den Sultau . . . . . . . . . . . f 74,600,000

2o. Kosten van 's lauds regeering . . . . . . . . . . - $474,800,000$

3o. Aflossing van leeuingen (payments on loans) . . . . . - 200,900,000

4o. Aanleg van spoorwegen en bijbehoorende werken ... . . - 118,700,000

50. Verschillende uitgaven voor het Suezkauaal, de dokken en havens te Suez, enz. euz. . . . . . . . . . . . - $141,800,000$

6o. Haven en dokken te Alexandrie, oprichting van kustlichten, enz. - 16,000,000

7o. Bruggen, graven en uitdiepen van kanalen enz. . . . . - 4,400,000

8o. Uilgaven tot verbetering van den gezondheidstoestand en tut verfraaiing te Alexandrie en Kairro. . . . . . . .

9o. Overnemen van de stoombootmaatschappij Azizieh, de mailen sleepdieusten, posterijen en de telegrafen in Soedan. .

10o. Aanzuivering in hoofdsom en reute van de schulden der weduwen- en weezenkas en der Medjidieh-maatschajpij, door den vorigen Ouderkoning aangegaan . . . . . . .

1 lo. Kosten tot bestrijding van de veepest (gedurende zeven jaren)

120. Aankoop vau een gepantserd oorlogschip, tot een geschenk an den Sultan bestemd . . . . . . . . . . .

13o. Voorschot aan landbouwers die wegens het dalen van den katoeuprijs hunne verplichtingen niet konden nakomen (terugbetaalbaar in 12 jaarl, termijnen, beginnende in $1873-74$ )

140. Voldoening van door de vorige regeering opgenomen verplichtingen jegens vreemde kooplieden en hoofdambtenaren .

15o. Kosten der expeditie van Sir Samuel Baker naar de Witte Nijl

16o. Commissie, kosten vau het vervaardigen van obligatien enz.

17\%. Rente op verschillende leeningen en rekening-couranten (vlottende schuld).

- $21,300,000$

- $52,000,000$

$6,800,000$

- $\quad 48,400,000$

$3,500,000$

$15,700,000$

$33,800,000$

$5,800,000$

18o. Overnemen der Société Agricole en betalen harer schulden. - $\mathbf{7}, 100,000$

Totaal . . $\overline{. f 1,383,700,000}$

Het nadeelig verschil van 176 millioen werd gedelst door de uitgifte van schatkistbiljetten, loopen van 1 tot 30 maanden, en van de zoogenaamde schatkistbiljetten der dorpen, warvan de laatste in 1874 vervallen zijn. Deze vlottende schuld zou echter worden geconsolideerd in de nog op rekening der leening van 1873 te ontvangen termijnen. Die leening namelijk is nominaal groot 32 millioen pd. st., waarvan niet meer dan 25 pCt., behoudens 
volstorting, op 10 Sept. 1873, den latsten dar van het Kuptische jaar 1589 , vervallen was.

De gevestigde achuld bestaat thans (*), sedert de leening van 1873 , tot op 15 Juli 1875, - want tot op dat tijdstip heeft de regeering van Egypte zich verbonden om geene nieuwe leening aan te gaan, - uit de volgende elementen :

\begin{tabular}{|c|c|c|c|c|}
\hline & & $\begin{array}{l}\text { Allosbiar } \\
\text { in: }\end{array}$ & $\begin{array}{l}\text { Oorspronkelijk } \\
\text { groot (in pd. st.) }\end{array}$ & $\begin{array}{l}\text { Restant up } 8 \text { Jau. } \\
1872 \text { (in pd. st.) }\end{array}$ \\
\hline Ireening & van 1862 & 1892 & $3,292,800$ & $2,883,000$ \\
\hline 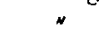 & "1864 & 1879 & $5,704,200$ & $3,923,800$ \\
\hline$"$ & " 1866 & 1874 & $3,000,000$ & $1,000,000$ \\
\hline$"$ & " 1868 & 1898 & $11,980,0 \cap 0$ & $11,493,500$ \\
\hline * & " 1873 & 1903 & $32,000,000$ & \\
\hline
\end{tabular}

De rentebetaling en aflossing vereischten tot in 1903 de volgende annuiteiten (in pr. st.) : in $18735,433,650$; in 1875-1879 4,916,747; in $1880-18914,226,410$; in $18924,164,065$; in $1893-1898$ $4,032,101$; in $1899-19033,078,804$.

Deze cijfers zijn zeker niet zeer geschikt om de aflossing en rentebetaling voor volkomen verzekerd te houden. Een schuldenlast van 670 millioen guldens, in tien jaren tijds gelegd op eene Oostersche natie van ruim 5 millioen zielen, wasran de welvaart en vooruitgang grootendeels wordt afgezogen en geneutraliseerd door tal van vreemde parasieten, die bij tractaten van alle belasting zijn vrijgesteld, is bedenkelijk hoog.

Slechts in twee gevallen is het aangaan van aanzienlijke staatsschulden niet af te keuren; wanneer er geld opgenomen wordt tot bestrijding van direct of indirect productieve uitgaven, of wanneer er gebroken moet worden met een verouderd en vicieus stelsel van financieel beheer en orde en regel in de financiën gebracht. $\mathrm{Nu}$ worden deze beide vereischten in het geval van Egypte wel gevonden, maar het komt ons voor dat ze niet krachtig genoeg op den voorgrond treden om het krediet van het land voor de toekomst boven elken twijfel te verheffen. Wanneer men den staat van uitgaven, tot welker bestrijding deze groote leeningen hebben moeten dienen nagaat, dan zal men er aanzienlijke posten op vinden wegens aanleg van spoorwegen en wegens het Suez-kanaal, groote werken die atellig vruchten zullen dragen. Maar het staat nog niet zoo vast of de financieele vruchten voor Egypte zelf wel zoo groot en zoo zeker zullen zijn. De ontworpen spoorwegen naar Sennaar en Kordofan zullen zekerlijk vooreerst

$\left({ }^{*}\right)$ 1874, Bovenstaand artikel, reeds voor eenigen tijd ingekomen, kon, tot ons leedwezen, wegens plaatsgebrek niet vroeger gepubliceerd worden. RED. 
wel geene groote sommen opbrengen, en van de spoorwegen in Neder-Egypte is het te vreezen dat zij al meer en meer een der elementen van voeding, het transport der Engelsche mailreizigers van Alexandrie narr Suez en terug, zullen verliezen. De ontvangsten uit dien hoofde zijn thans nog vrij aanzienlijk, maar het Suezkanaa! zal ze weldra doen ophouden, en niemand zal willen beweren dat Egypte ooit eenige noemenswaardige rente zal trekken van de millioenen bij millioenen, die het aan dat werk heeft ten koste gelegd. Productief belegd kan men dus maar een gedeelte der sedert 1862 geleende gelden noemen, en dan nog slechts tot eene zekere hoogte.

Voor een aanzienlijk deel is uit de opbrengst dier leeningen leergeld betaald voor oude zonden. De 143 millioen voor vlottende schuld, de 15, en nog eons 6 millioen voor de gevolgen van Saïd Pacha's onnadentrendheid en spilzucht, de 33 millioon bakschisch door hem toegekend, - vallen in deze categorie. Bij herbaling vernemen wij dat de Onderkoning en zijne ministers, door de ondervinding geleerd, roortaan wel zorgen zullen dat er orde in de finaucien zij, en dat de uitgaven de begrootingen de inkomsten niet meer overschrijden. Zoolang echter die goede gezindheid alleen uit woorden en betuigingen blijkt, kan daaraan geen groote blijvende waarde worden gehecht. Al beeft men te Kaïro een schijn van constitutioneele instellingen, Egypte is en blijft een Oostersch land, een land van het persoonlijk gonvernement, waar de geheele politiek der regeering af bangt van de luimen des heerschers.

Op het financieele gebied ligt trouwens het groote gevaar voor Egypte's toekomst. De natuur heeft het land rijk en gunstig gelegen gemaakt; de bevolking is rustig en werkzaam, ook al mist ze de veerkracht, die de "zachte dwang" van den verplichten arbeid niet lang bij den menseh bestaan laat. Met eene bevolking die weinig behoeften heeft en dus niet getrokken wordt tot de industrie, maakt de regeering zich opvolgend van de meeste takken van nijverheid meester, en het geid stroomt haar van alle kanten toe. Blijkens een merkwardig staatje van den heer de Regny, werd er in 1863-1872 voor fr. 441,194,644 meer in- dan uitgevoerd aan numerair, boofdzaizelijk ten bate der regeering, zij bet al niet als zoodanig dan toch als de grootste industrieel des lands. Wat wonder, zoo eene regeering, in zoo groote ruimte van geld verkeerende, roekeloos wordt en, riet aan zelf beheersching en eigen contrôle gewoon, tot allerlei financieele buiten- 
sporigheden overslaat? Zoo de schatkist ledig is, staan de bankiers met voorschotten gereed; wel stellen zij zeer bezwarende voorwaarden, maar geld bezorgen kunnen zij altijd, omdat de Esyptische obligatien eene willige markt vinden op de beurzen van Europa. Als een bewijs van die willigheid kan dienen dat in 1870 van de gevestigde schuld van Egypte een nominaal bedrag van 23,347,000 pd. st. in Europa, en niet meer dan 630,000 pd. st. in het land zelf geplaatst was. Ook de leening van 1873 zal warrschijnlijk wel hoofdzakelijk in Europa blijven.

In deze laatste broze en onzekere betrekking tusschen Europa en Egypte beeft Nederland een niet gering aandeel. Jawmer echter dat ons land eerst in bet allerlaatste gelid staat van de natiën, die handelsbetrekkingen met Egypte onderhouden. In het geheel liepen slechts 14 koopvaardijschepen onder Nederiandsche vlag in het tijdvak 1863-1872 de haven van Alexandrie binnen. De goederen in die jaren uit die baven naar Nederland uitgevoerd hadden eene waarde van 245,533 piasters (iets meer dan $f 30,000)$; de directe invoer uit Nederland beliep nikil.

Hoe lang in dit opzicht ons land staat blijkt uit de volgende opgave van alle in Alexandrie binnengekomen koopvaardijschepen (met uitzondering van pakketbooten) en de in dit cijfer begrepen vaartuigen onder Nederlandsche, Belgische en Zweedsche vlag.

18632397 schepen, waaronder 1 Ned., 2 Belg., $4 \mathrm{Zw}$.

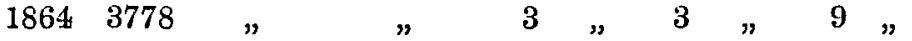

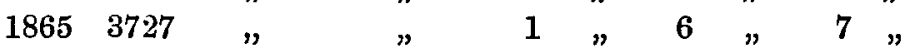

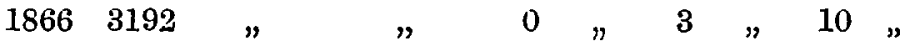

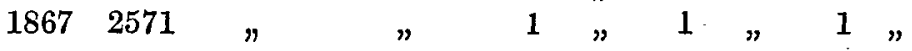

$18681996 \quad " \quad$ " $\quad 0 \quad \% \quad 7 \quad 7 \quad 0$ "

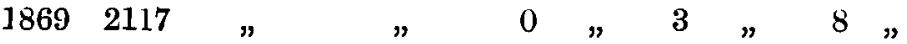

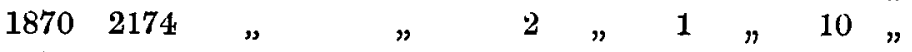

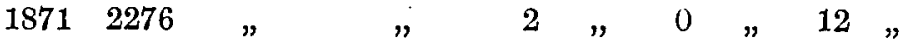

$18722389 " \quad$ " 4 " 0 n $5 "$

Toch ontbreken geschikte artikelen van invoer voor Egypte den Nederlandschen bandel niet. Onder de te Alexandrie ingevoerde artikelen treffen wij aan boter, waskaarsen, tabak, koffie, likeuren, manufacturen, tin, thee en in het algemeen alle artikelen van verbruik voor de talrijke Europeesche bevolking in de steden van Neder-Egypte.

Aan de internationale handelsbeweging. door het Suez-kanaal heeft Nederland, dank vooral aan de pogingen van prins Hendrik 
der Nederlanden, thans een billijk aandeel; alweder door de zorgen ran den doorluchtigen prins waait onze vlag op Figyptiseb grondgebied, aan de invaart vau het kanaal. Hopen wij dat het boogere cijfer onzer in de laatste jaren te Alexandrie aangekomen schepen een bewijs is van verlevendiging van het verkeer met Egypte, opdat het aldaar blijken moge dat de van ouds nijvere en arbeidzame Nederlandsche natie nog niet is afgedaald tot de stelling van een klein rentenier, die bovendien bij de plaatsing van zijn kapitaal niet altijd even voorzichtig te werk gaat.

Mr. A. M. Maas Geesteranos. 